\title{
CHEK1 Gene Mutation
}

National Cancer Institute

\section{Source}

National Cancer Institute. CHEK1 Gene Mutation. NCI Thesaurus. Code C131788.

A change in the nucleotide sequence of the CHEK1 gene. 